УДК 676.1.054.1

\title{
ФИЗИКО-МЕХАНИЧЕСКИЕ СВОЙСТВА ТРУДНОВОСПЛАМЕНЯЕМЫХ ДРЕВЕСНОВОЛОКНИСТЫХ ПЛИТ
}

\author{
(C) А.В. Антонов ${ }^{1}$, Н.А. Петрушева ${ }^{2 *}$, Ю.Д. Алашкевич ${ }^{3}$ \\ ${ }^{1}$ Сибирская пожарно-спасательная академия - фиилиал Санкт- \\ Петербургского университета ГПС МЧС России, ул. Северная, 1, \\ Железногорск, Красноярский край, 662972 (Россия), e-mail: sanches12@mail.ru \\ ${ }^{2}$ Лесосибирский фрилиал Сибирского государственного технологического \\ университета, ул. Победы, 29, Лесосибирск, 662543 (Россия), \\ e-mail: info@lfsibgtu.ru \\ ${ }^{2}$ Сибирский государственный технологический университет, пр. Мира, 82, \\ Красноярск, 660049 (Россия), e-mail: mapt@sibgtu.ru
}

Представлены результаты исследований по установлению влияния технологических и конструктивных параметров процесса получения древесноволокнистой массы в производстве трудновоспламеняемых древесноволокнистых плит на физико-механические свойства готовой продукции при условии сохранения последних на требуемом уровне. Для решения поставленной задачи в работе были использованы методы математического планирования с целью получения математического описания процесса размола древесноволокнистой массы при изготовления древесноволокнистых плит со сниженной пожарной опасностью. Построение математических моделей объекта является важнейшей составной частью научного исследования. Разработанные математические модели объекта являются хорошим инструментом исследования. Полученные в работе уравнения, описывающие исследуемые процессы подготовки древесноволокнистых материалов, адекватны и, на наш взгляд, позволяют прогнозировать получение качественных древесноволокнистых плит со сниженной пожарной опасностью в зависимости от установленных режимов процесса размола. При известных значениях массовой доли вспученного вермикулита в древесноволокнистой композиции, варьируя значения конструктивных и технологических параметров размалывающих установок, возможно не только понизить группу горючести плит по ГОСТ 12.1.044-89 «Пожаровзрывоопасность веществ и материалов. Номенклатура показателей и методы их определения» до уровня трудновоспламеняемых, но и поддерживать физико-механические показатели твердых древесноволокнистых плит в пределах требований ГОСТа 4598-86 «Плиты древесноволокнистые. Технические условия».

Ключевые слова: древесноволокнистая плита, пожарная опасность, предел прочности при статическом изгибе, водопоглощение, математическое описание.

\section{Введение}

Древесноволокнистые плиты (ДВП) - листовой материал, изготовленный в процессе горячего прессования или сушки массы из древесного волокна, сформированного в виде ковра. Древесные волокна это мелкие древесные частицы, представляющие собой отдельные клетки, их обрывки или группы клеток

Антонов Александр Викторович - начальник отдела прикладных исследований и инновационных технологий, кандидат технических наук, e-mail: sanches12@mail.ru Петрушева Надежда Александровна - доцент кафедры технологии лесозаготовительных и деревоперерабатывающих производств, кандидат технических наук, e-mail: info@1fsibgtu.ru Алашкевич Юрий Давыдович - заведующий кафедрой машин и аппаратов промышленных технологий, доктор технических наук, профессор, e-mail: mapt@sibstu.kts.ru древесины.

К физическим свойствам ДВП относятся: плотность, влажность, водопоглощение, разбухание, усадка, линейное удлинение, теплопроводность, звукопоглощение и др. Механические свойства древесноволокнистых плит - это прочность на изгиб, растяжение параллельно и перпендикулярно пласти, твердость и др.

\footnotetext{
* Автор, с которым следует вести переписку.
} 
Одна из ответственных операций в технологии производства древесноволокнистых плит, от качества которой в дальнейшем зависят процессы отлива и обезвоживания ковра, процессы прессования и термовлагообработки плит - подготовка древесноволокнистой массы (размол).

Древесноволокнистое полотно, отлитое из неразмолотых волокон, получается неудовлетворительным по своему строению, внешнему виду и физико-механическим свойствам. Неразмолотые волокна обладают малой пластичностью, слабо развитой поверхностью и мало гидротированы, вследствие чего такие волокна плохо связываются друг с другом в плите.

От степени размола зависят качественные показатели готовых плит. Сопротивление плит изгибу и сопротивление разрыву в первом приближении изменяется пропорционально степени размола древесноволокнистой массы, а водопоглощение и набухание плит уменьшаются при возрастании степени размола [1]. Хотя количественные данные о влиянии степени размола на свойства плит различаются у разных авторов $[2,3]$, в среднем можно принять, что изменение степени размола на одну дефибратор-секунду (1 ДС) приводит к изменению сопротивления на изгиб на 1,5-2,0 МПа. Такие колебания механических свойств плит резко снижают их достоинства как однородного материала, а часть продукции приходится переводить в более низкую категорию - из твердых в полутвердые плиты [4].

Согласно теории структурообразования плит [5] плита состоит из армирующих микроструктуру волокон, образующих пространственную сетку, поры которой заполнены неволокнистыми компонентами, мелкодисперсной волокнистой фракцией, воздухом и водой. В предложенной модели структуры плиты межволоконные контакты имеют связи адгезионного и когезионного характера. Определяющие их параметры (удельная прочность и энергия разрушения межволоконных контактов) зависят от количества и свойств введенных неволокнистых компонентов и мелковолокнистой фракции.

Минерал (вспученный вермикулит), который предлагается вводить в структуру древесноволокнистой плиты с целью снижения ее пожарной опасности, является, естественно, неволокнистым компонентом, оказывающим значительное влияние на образование связей в плите, а, следовательно, и на ее физикомеханические свойства. В связи с этим можно предположить, что древесноволокнистая масса для производства плит со сниженной пожарной опасностью должна характеризоваться более длинными волокнами, так как определенное количество мелкой фракции, обеспечивающей увеличение показателя общей площади, на которой устанавливаются связи, будет замещено частицами минерала [6].

Таким образом, в представленной работе была поставлена задача установления влияния технологических и конструктивных параметров процесса получения древесноволокнистой массы в производстве трудновоспламеняемых древесноволокнистых плит на физико-механические свойства готовой продукции при условии сохранения последних на требуемом уровне. Для решения поставленной задачи в работе были использованы методы математического планирования с целью получения математического описания процесса размола древесноволокнистой массы при изготовления древесноволокнистых плит со сниженной пожарной опасностью [7].

Построение математических моделей объекта является важнейшей составной частью научного исследования. Цель наших экспериментальных исследований - получение эмпирических математических моделей, описывающих исследуемый объект, т.е. отыскание зависимости каждой из выходных величин объекта от варьируемых факторов. Разработанные математические модели объекта являются хорошим инструментом исследования. С их помощью можно определить интересующие характеристики объекта, результаты влияния на него тех или иных факторов, оптимальные режимы функционирования и способы управления объектом.

\section{Экспериментальная часть}

В данной работе для построения математической модели процесса, проверки ее адекватности и оценки влияния на процесс каждого учитываемого технологического фактора использован регрессионный анализ - метод, который позволяет устанавливать значения факторов и диапазоны их варьирования по своему усмотрению, не нарушая хода технологического процесса, согласно технических характеристик применяемого оборудования, требований стандартов к готовой продукции и т.п. [7]. Для получения регрессионных зависимостей был реализован В-план второго порядка.

На основании анализа литературных источников и проведенных ранее [8-11] экспериментов в качестве управляемых параметров экспериментальных исследований были выбраны: 
а) первая ступень размола:

- износ сегментов $L / h(10-90 \%$ с интервалом варьирования 40\%);

- зазор между дисками $z$ (0,05-0,15 мм с интервалом варьирования 0,05 мм);

- скорость вращения нижнего шнека $n$ (12-15,4 об/мин с интервалом варьирования 1,7 об/мин);

- массовая доля вермикулита в древесноволокнистой композиции $\omega_{6}$, $(10-50 \%$ к а.с.в. с интервалом варьирования $20 \%$ к а.с.в.);

б) вторая ступень размола:

- износ сегментов $L / h(10-90 \%$ с интервалом варьирования 40\%);

- зазор между дисками $z$ (0,05-0,15 мм с интервалом варьирования 0,05 мм);

- концентрация древесноволокнистой массы $c$ (2,5-3,5\% с интервалом варьирования 0,5\%);

- массовая доля вермикулита в древесноволокнистой композиции $\omega_{6}$, $(10-50 \%$ к а.с.в. с интервалом варьирования 20\% к а.с.в.).

Были выбраны следующие контролируемые параметры:

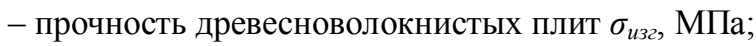

- водопоглощение за 24 ч $S, \%$.

К неконтролируемым факторам эксперимента относились не указанные выше геометрические и физико-механические характеристики процесса.

Исследования по размолу древесноволокнистых полуфабрикатов осуществлялись на промышленных установках завода ДВП ОАО «Лесосибирский ЛДК №1», а также на экспериментальных и полупромышленных установках лаборатории лесоперерабатывающей, целлюлозно-бумажной и химической технологии древесины Лесосибирского филиала СибГТУ.

В качестве исходного сырья для получения древесноволокнистой массы использовались исключительно древесные отходы лесопильного производства и низкокачественная древесина со склада сырья, породного состава $93 \pm 3,4 \%$ хвойных пород.

Для придания древесноволокнистым плитам специальных свойств в качестве наполнителя применяли вспученный вермикулит $[12,15]$. В наших исследованиях был использован вспученный вермикулит по ГОСТ 12865-67 плотностью 200 кг/м³ , мелкий — с размером фракций до 0,6 мм.

Размерные и физико-механические характеристики готовой плиты (толщина, предел прочности при статическом изгибе, водопоглощение) определялись по ГОСТ 19592-80 «Плиты древесноволокнистые. Методы испытаний».

\section{Обсуждение результатов}

В результате реализации многофакторного эксперимента были получены математические модели с нормализованными обозначениями факторов, отражающие влияние каждого исследуемого фактора на выходные величины в отдельности с учетом парных взаимодействий факторов друг на друга и на выходную величину.

Размол щепь (I ступень размола - дефибратор). Зависимости прочности и водопоглощения за 24 ч от массовой доли вспученного вермикулита, конструктивных и технологических параметров дефибратора:

$$
\begin{aligned}
& \sigma_{\text {изг }}=28,2+0,08 L / h+31,7 z-1,6 n+0,07 \omega_{b}+16 z^{2}-0,04 n^{2}+1,9 L / h z-2,35 z \omega_{b}+0,012 n \omega_{b} ; \\
& S=7,03+1,76 L / h+25 z+0,4 n+0,44 \omega_{6}-0,1 L / h^{2}-13,2 z^{2}-0,4 L / h z+0,02 L / h n-0,03 L / h \omega_{b}+ \\
& +2,82 z n-0,5 z \omega_{b}-0,02 n \omega_{6} \text {. }
\end{aligned}
$$

Математические зависимости $(1,2)$ представляют собой уравнения регрессии. Графики, наглядно демонстрирующие данные зависимости исследуемых факторов, представлены на рисунках 1-4.

Анализ приведенных зависимостей показывает, что наибольшее влияние на исследуемые показатели оказывает величина зазора между дисками дефибратора. Для показателя прочности ДВП большое значение будет иметь также и скорость вращения нижнего шнека размольного агрегата, так как достижение максимальных значений прочности возможно лишь при определенной степени разработанности древесноволокнистой массы, что требует увеличение продолжительности размола (рис. 1-4).

Сравнительный анализ графиков на рисунке 1 показывает совместное влияние зазора между дисками и скорости вращения нижнего шнека дефибратора на прочность плит. При значениях $n=12$ об/мин изме- 
нение зазора между дисками от 0,05 мм до 0,1 мм дает лишь небольшое колебание значений прочности плиты - около $5 \%$, при значении $n=13,7$ об/мин то же изменение зазора однозначно вызывает снижение прочности ДВП примерно на $11 \%$, при величине $n=15,4$ об/мин уменьшение прочности становится более значительным - около $23 \%$ (рис. 1в). Однако дальнейшее увеличение зазора до 0,15 мм оказывает благоприятное влияние на величину прочности плит $\left(\sigma_{\text {изг }}=33,6 \mathrm{MПа}\right)$.

Анализ графических зависимостей, представленных на рисунке 2, позволяет оценить совместное влияние на прочность плит величины зазора между размалывающими дисками дефибратора и массовой доли вермикулита в древесноволокнистой плите. Очевидно, что неволокнистый компонент оказывает негативное влияние на величину прочности. На наш взгляд, это связано с тем, что мелкие зерна вермикулита не только внедряются в древесные волокна сравнительно большого диаметра, но и замещают часть мелких волокон, создающих дополнительные связи в плите. Поскольку количество мелких волокон сокращается, связей между армирующими волокнами ставится меньше, прочность плит снижается: максимальное значение прочности при $\omega_{6}=10 \%$ равно $\sigma_{\text {изе }}=36 \mathrm{MПа;} \mathrm{при} \omega_{6}=30 \%$ равно $\sigma_{\text {изг }}=34,6 \mathrm{MПа;} \mathrm{при} \omega_{6}=50 \%$ равно $\sigma_{\text {изг }}=33,8$ МПа.

Как было сказано выше, наибольшее влияние на величину водопоглощения $S$ оказывает изменение зазора между дисками дефибратора (рис. 3).

Водопоглощение древесноволокнистых плит ухудшается с увеличением зазора между размалывающими дисками дефибратора и скорости вращения нижнего шнека примерно на $36 \%$, так как щепа не успевает в достаточной мере пропариваться, идет быстрая выгрузка пропарочной камеры, увеличиваются давление в размольной камере, скорость прохождения щепы через размольную камеру, в составе древесноволокнистой массы присутствуют неразмолотые пучки волокон, спички. С увеличением скорости вращения нижнего шнека на дефибраторе качество массы на второй ступени размола резко снижается в связи с тем, что рафинатор не может переработать грубую, плохо пропаренную массу после дефибратора.

Вторым по оказываемому влиянию является износ сегментов размалывающей гарнитуры (рис. 4).

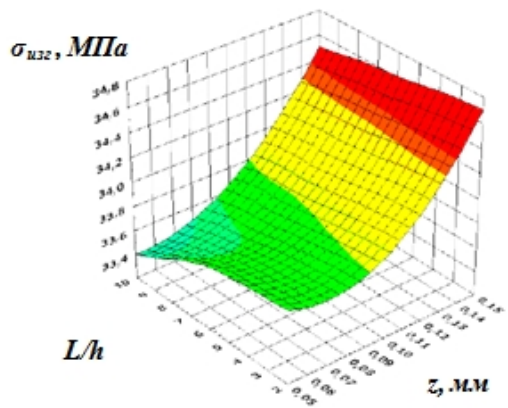

$a-n=12$ об/мин

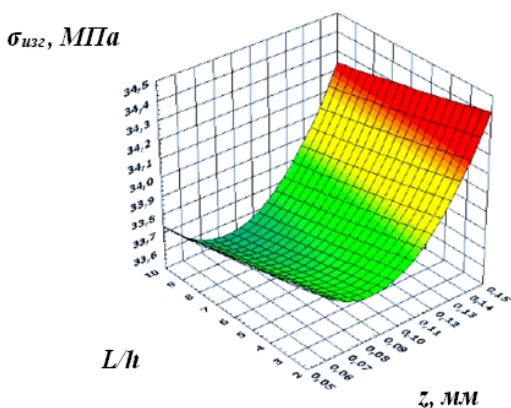

$\sigma-n=13,7$ об/мин

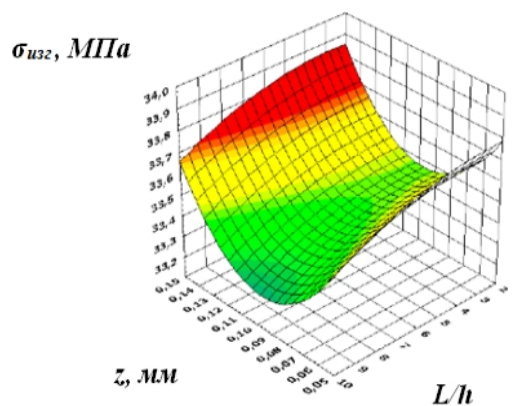

$в-n=15,4$ об/Мин

Рис. 1. Зависимость прочности ДВП от степени износа дисков и зазора между дисками дефибратора $\left(\omega_{\mathrm{B}}=30 \%\right)$
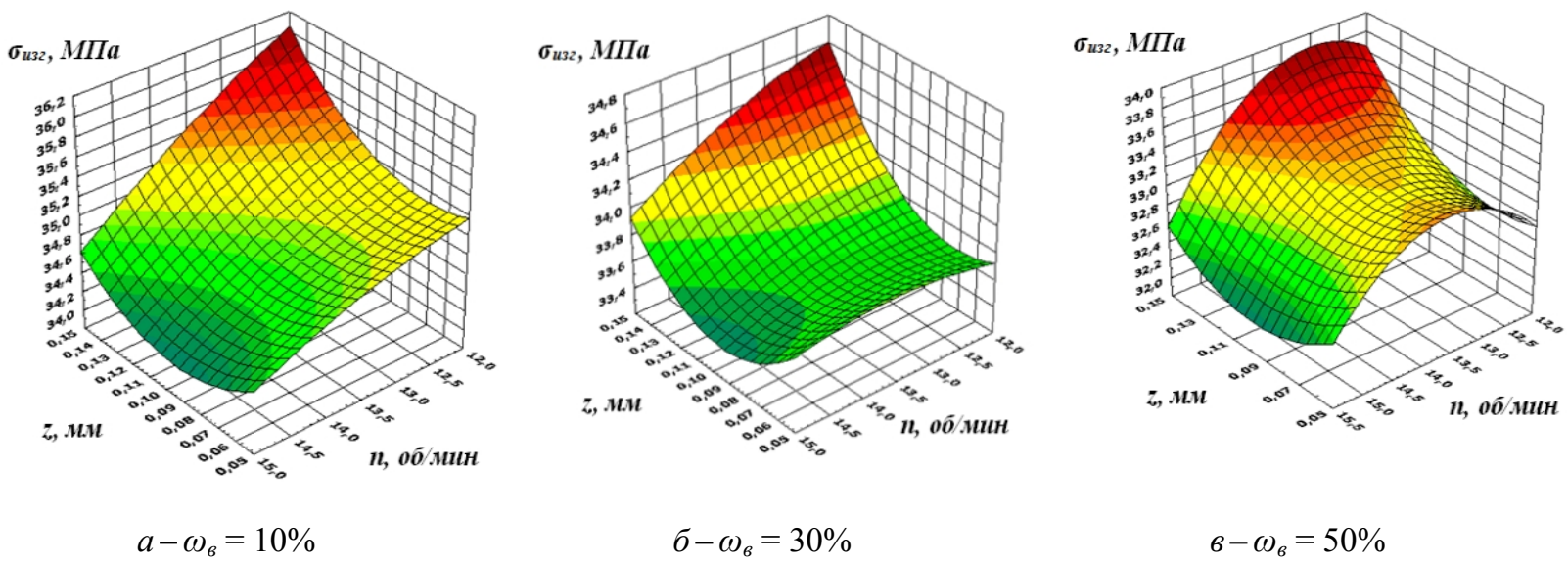

Рис. 2. Зависимость прочности ДВП от зазора между дисками дефибратора $(L / h=6)$ 

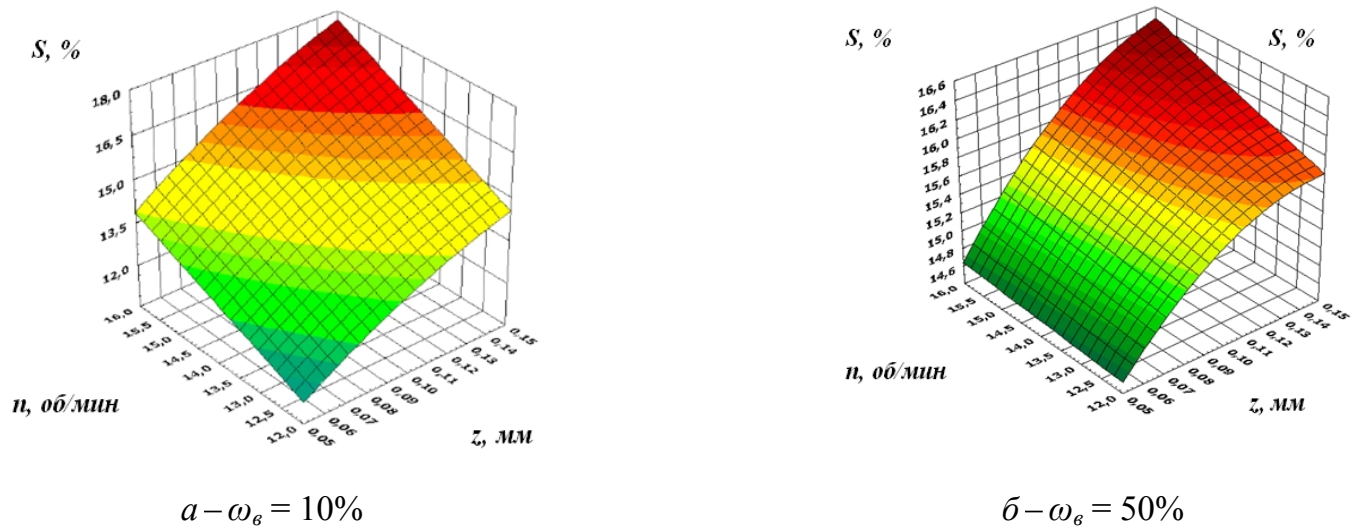

Рис. 3. Зависимость водопоглощения ДВП от зазора между дисками дефибратора $(L / h=6)$
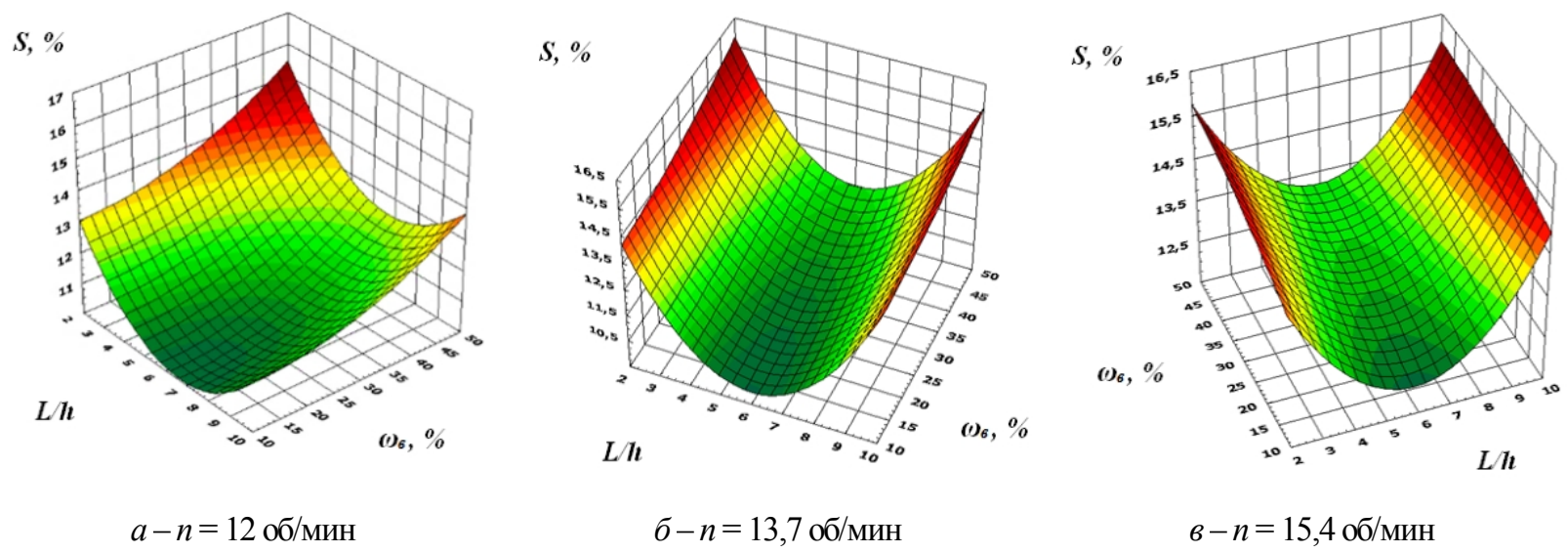

Рис. 4. Зависимость водопоглощения ДВП от износа сегментов размалывающей гарнитуры дефибратора $(z=0,1 \mathrm{мм}, n=12$ об/мин)

Как видно из рисунка $4 \mathrm{a}$, большой износ сегментов размалывающей гарнитуры также негативно сказывается на водопоглощении ДВП, как и малый: $S=15,6 \%$ при $L / h=10 ; S=15,8 \%$ при $L / h=2$. При малом износе сегментов размалывающей гарнитуры происходит интенсивная рубка волокон, гидратирующие воздействие сведено к минимуму, что приводит к наличию в древесной массе большого количества крупной и мелкой фракций, спичек, неразмолотых пучков волокон, волокна практически не фибриллированы, количество волокна средней фракции очень мало. При большом износе сегментов волокно подвергается истиранию, смятию и рубке, внешняя фибрилляция также очень мала, однако имеет место внутренняя фибрилляция, что несколько улучшает качество массы, вследствие чего показатели водопоглощения сравнительно улучшаются.

Анализ графиков на рисунках 3 и 4 дополнительно позволяет нам оценить влияние, которое оказывает изменение массовой доли вермикулита в древесноволокнистой композиции на водопоглощение готовых плит. Значительное ухудшение водопоглощения наблюдается при увеличении массой доля минерала до $50 \%$. При среднем износе сегментов и оборотах нижнего шнека 12-13,7 об/мин увеличение массовой доли минерала до 10-30\% позволяет получить плиту с удовлетворительными значениями водопоглощения $S=10,2-10,5 \%$.

Размол древесноволокнистой массы (II ступень размола - рафинатор). Зависимости прочности и водопоглощения за 24 ч от массовой доли вспученного вермикулита, конструктивных и технологических параметров рафинатора:

$$
\begin{aligned}
& \sigma_{u з 2}=45,05+0,58 L / h-36 z+5,82 c-0,27 \omega_{b}-60 z^{2}+0,92 c^{2}+0,002 \omega_{b}{ }^{2}-1,6 L / h z+0,21 L / h c- \\
& -0,01 L / h \omega_{B}+0,52 z \omega_{B}-0,01 c \omega_{B} \text {; } \\
& S=2,25+1,07 L / h+6,8 z+8,3 c+0,46 \omega_{6}-0,085 L / h^{2}-10,4 z^{2}-0,8 c^{2}+0,002 \omega_{b}{ }^{2}-0,104 c \omega_{6} .
\end{aligned}
$$

Графики, наглядно демонстрирующие данные зависимости исследуемых факторов, представлены на рисунках 5-6. 

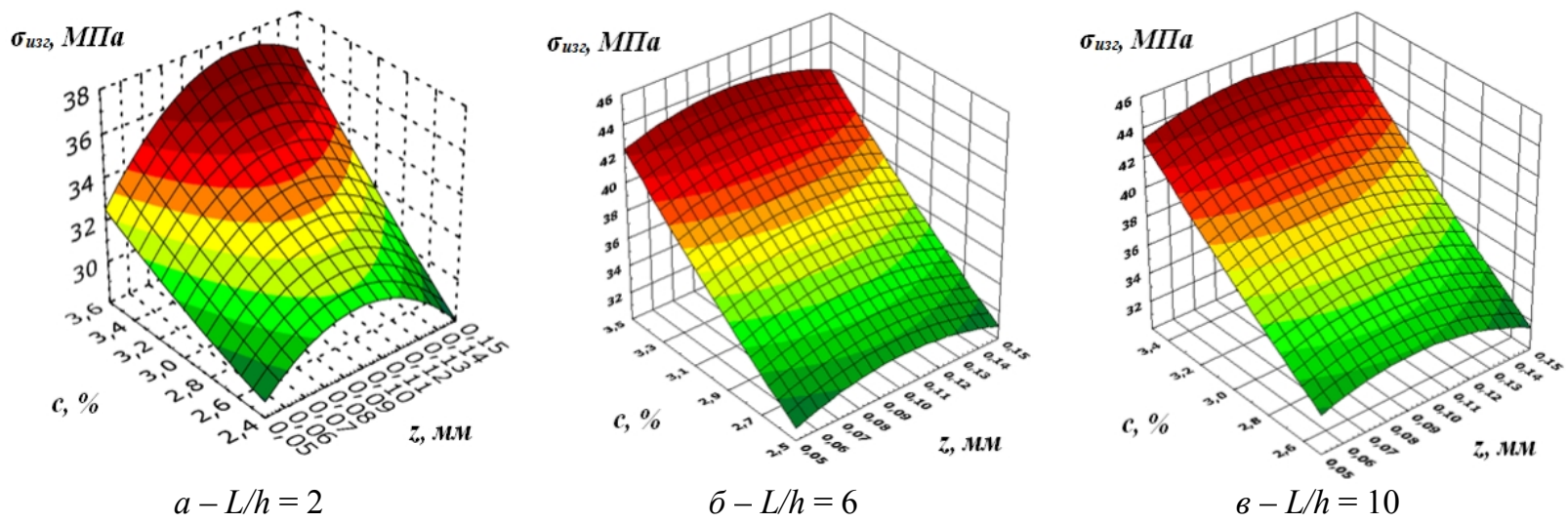

Рис. 5. Зависимость прочности ДВП от зазора между размалывающими дисками $\left(\omega_{6}=30 \%\right)$
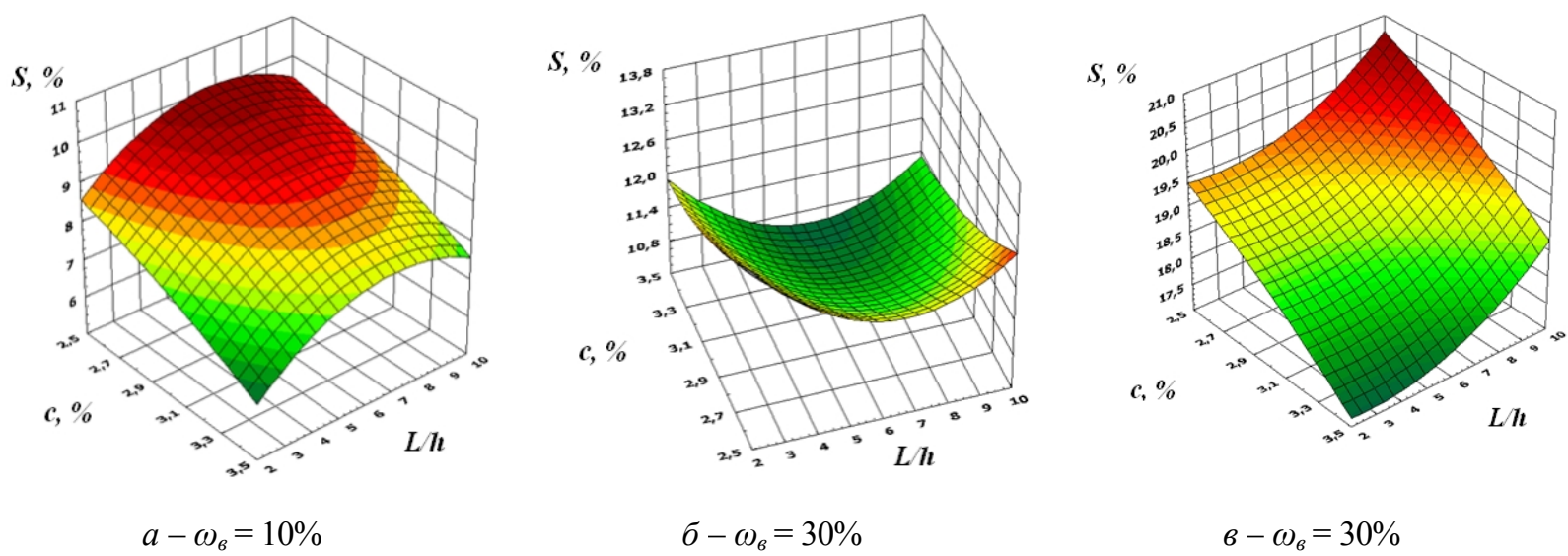

Рис. 6. Зависимость водопоглощения ДВП от концентрации массы перед рафинатором $(z=0,1$ мм $)$

Анализ графиков и уравнений показал следующее. Влияние зазора между размалывающими дисками на прочность древесноволокнистых плит с вермикулитом можно увидеть на всех трех графиках, представленных на рисунке 5 - с увеличением зазора от 0,05 до 0,1 мм прочность возрастает, при дальнейшем увеличении зазора до 0,15 мм значения прочности постепенно снижаются. Характер этого влияния несколько меняется в зависимости от износа сегментов гарнитуры - при износе $10 \%$ увеличение зазора от 0,05 до 0,1 мм способствует более резкому увеличению прочности плит, при износе 50 и $90 \%$ кривые изменения прочности носят более плавный характер. При анализе графиков на рисунке 5 также можно заметить, что при 10-типроцентном износе сегментов размалывающей гарнитуры максимальных значений величина прочности плит достигает при размоле древесноволокнистой массы концентрацией $3 \%$, при увеличении износа сегментов до 50 и 90\% наибольших значений величина прочности достигает при размоле массы с концентрацией 3,5\%.

На рисунке 6 представлены графические зависимости водопоглощения от значений концентрации массы перед рафинатором при различных значениях износа сегментов размалывающей гарнитуры и массовой доли вермикулита в древесноволокнистой композиции, величина зазора между дисками фиксирована на $z=0,1$ мм. Анализ уравнения (4) показывает, что концентрация массы перед рафинатором имеет наибольшее влияние на значения водопоглощения плит. Увеличение массовой доли вермикулита ухудшает значения водопоглощения независимо от варьирования других факторов с значений $S=8 \%$ при $\omega_{\beta}=10 \%$ до $S=18,6 \%$ при $\omega_{в}=50 \%$.

\section{Выводы}

Полученные в работе уравнения, описывающие исследуемые процессы подготовки древесноволокнистых материалов, адекватны и, на наш взгляд, позволяют прогнозировать получение качественных древесноволокнистых плит со сниженной пожарной опасностью в зависимости от установленных режимов процесса размола. При известных значениях массовой доли вспученного вермикулита в древесноволокни- 
стой композиции, варьируя значения конструктивных и технологических параметров размалывающих установок, возможно не только понизить группу горючести плит по ГОСТ 12.1.044-89 «Пожаровзрывоопасность веществ и материалов. Номенклатура показателей и методы их определения» до уровня трудновоспламеняемых, но и поддерживать физико-механические показатели твердых древесноволокнистых плит в пределах требований ГОСТ 4598-86 «Плиты древесноволокнистые. Технические условия».

\section{Список литературы}

1. Леонович А.А. Физико-химические основы образования древесных плит. СПб., 2003. 192 с.

2. Ласкеев П.Х. Производство древесной массы. Л., 1967. 180 с.

3. Бекетов В.Д. Повышение эффективности производства древесноволокнистых плит. М., 1988. 158 с.

4. Баженов В.А., Карасев Е.И., Мерсов Е.Д. Технология и оборудование производства древесных плит и пластиков. М., 1980. $360 \mathrm{c.}$

5. Чистова Н.Г. Переработка древесных отходов в технологическом процессе производства древесноволокнистых плит : дис. ... д-ра техн. наук. Красноярск, 2010. 414 с.

6. Антонов А.В., Петрушева Н.А., Алашкевич Ю.Д. Получение огнезащищенных древесноволокнистых плит // Известия вузов. Лесной журнал. 2012. №4. С. 99-104.

7. Пижурин А.А. Исследование процессов деревообработки. М., 1984. 232 с.

8. Антонов А.В., Алашкевич Ю.Д., Петрушева Н.А. О прочности древесноволокнистых плит со специальными свойствами // Наука и современность - 2010: сб. ст. по материалам VII междунар. науч.-практ. конф. Новосибирск, 2010. С. 11-15.

9. Антонов А.В., Петрушева Н.А., Чижов А.П., Алашкевич Ю.Д. Влияние технологических и конструктивных параметров размола на свойства трудновоспламеняемых древесноволокнистых плит // Химия растительного сырья. 2012. №4. С. 215-219.

10. Антонов А.В., Алашкевич Ю.Д., Петрушева Н.А., Чижов А.П. Получение древесноволокнистых плит специального назначения с использованием вермикулита // Древесные плиты: теория и практика : сб. ст. по материалам XIV Междунар. науч.-практ. конф. СПб., 2011. С. 71-73.

11. Антонов А.В., Алашкевич Ю.Д., Петрушева Н.А., Чижов А.П. Возможность получения древесноволокнистых плит со специальными свойствами // Лесной и химический комплексы - проблемы и решения : сб. ст. по материалам Всерос. науч.-практ. конф. Красноярск, 2011. Т. 1. С. 202-204.

12. Антонов А.В., Петрушева Н.А., Чижов А.П., Ярошенко К.О., Мухамедшина Л.М. Использование вермикулита в производстве древесноволокнистых плит // Молодые ученые в решении актуальных проблем науки : сб. ст. по материалам Всерос. науч.-практ. конф. с междунар. участием. Красноярск, 2011. Т. 2. С. $62-64$.

13. Антонов А.В., Алашкевич Ю.Д., Петрушева Н.А., Чижов А.П. Обоснование использования вермикулита в производстве ДВП со специальными свойствами // Новые достижения в химии и химической технологии растительного сырья : сб. материалов V Всерос. конф. с междунар. участием. Барнаул, 2012. С. 429-432.

Поступило в редакиию 21 января 2016 г.

После переработки 3 марта 2016 г. 
Antonov A.V. ${ }^{l}$, Petrusheva N.A. ${ }^{2 *}$, Alashkevich Y.D. ${ }^{3}$ PHYSICO-MECHANICAL PROPERTIES OF FLAME RETARDANT FIBERBOARD

${ }^{I}$ Siberian fire and rescue Academy - branch of St. Petersburg University of state fire service of EMERCOM of Russia,

North St, 1, Zheleznogorsk, Krasnoyarsk region, 662972 (Russia),e-mail: sanches12@mail.ru

${ }^{2}$ Lesosibirsk branch of Siberian state technological University, Pobedy st., 29, Lesosibirsk, 662543 (Russia), e-mail:info@lfsibgtu.ru

${ }^{3}$ Siberian state technological University, Mira, 82, Krasnoyarsk, 660049 (Russia),e-mail: mapt@sibgtu.ru

The paper presents the results of studies to establish the influence of technological and constructive parameters of the process of producing a wood-fiber mass in the manufacture of flame retardant hardboard on the physico-mechanical properties of finished products while maintaining the latter at the required level. For the task solution in the work there were used methods of mathematical planning with the aim of obtaining the mathematical description of grinding process of wood-fiber mass during the manufacture of hardboard panels with a reduced fire hazard. Construction of mathematical models of object is an important part of scientific research. Developed mathematical model of the object are a good research tool. Obtained equations describing the studied processes of preparation of wood-fiber materials, and adequate, in our view, allow for obtaining high-quality MDF panels with a reduced fire hazard depending on the set modes of the milling process. At known values of the mass fraction of expanded vermiculite in wood-fiber composition and by changing the values of constructive and technological parameters of the refining units, it is possible not only to reduce the inflammability level of the slabs according to GOST 12.1.044-89 "fire and explosion hazards of substances and materials. Nomenclature of indices and methods of their determination" to the level of flame retardant, but also to maintain physical and mechanical properties of solid wood-fiber plates within the requirements of GOST 4598-86 "fiberboard Plate. Technical conditions".

Keywords: fiberboard, fire danger, the ultimate strength in static bending, water absorption, mathematical description.

\section{References}

1. Leonovich A.A. Fiziko-khimicheskie osnovy obrazovaniia drevesnykh plit. [Physical and chemical bases of education wallboards]. St. Petersburg, 2003, 192 p. (in Russ.).

2. Laskeev P.Kh. Proizvodstvo drevesnoi massy. [Production of wood pulp]. Leningrad, 1967, 180 p. (in Russ.).

3. Beketov V.D. Povyshenie effektivnosti proizvodstva drevesnovoloknistykh plit. [Increasing the efficiency of production of fibreboard]. Moscow, 1988, 158 p. (in Russ.).

4. Bazhenov V.A., Karasev E.I., Mersov E.D. Tekhnologiia i oborudovanie proizvodstva drevesnykh plit $i$ plastikov. [Technology and equipment for the production of wood-based panels and plastics]. Moscow, 1980, 360 p. (in Russ.).

5. Chistova N.G. Pererabotka drevesnykh otkhodov a tekhnologicheskom protsesse proizvodstva drevesnovoloknistykh plit : dis. ... dokt. tekhn. nauk. [Recycling wood waste in the process of production of fibreboard: the dissertation of the doctor of technical sciences]. Krasnoyarsk, 2010, 414 p. (in Russ.).

6. Antonov A.V., Petrusheva N.A., Alashkevich Iu.D. Izvestiia vuzov. Lesnoi zhurnal, 2012, no. 4, pp. 99-104. (in Russ.).

7. Pizhurin A.A. Issledovanie protsessov derevoobrabotki. [Woodworking processes Research]. Moscow, 1984, 232 p. (in Russ.).

8. Antonov A.V., Alashkevich Iu.D., Petrusheva N.A. Nauka i sovremennost' - 2010: sb. st. po materialam VII mezhdunar. nauch.-prakt. konf. [Science and the present - 2010: Proceedings of the VII International Scientific and Practical Conference]. Novosibirsk, 2010, pp. 11-15. (in Russ.).

9. Antonov A.V., Petrusheva N.A., Chizhov A.P., Alashkevich Iu.D. Khimiia rastitel'nogo syr'ia, 2012, no. 4, pp. $215-219$. (in Russ.).

10. Antonov A.V., Alashkevich Iu.D., Petrusheva N.A., Chizhov A.P. Drevesnye plity: teoriia i praktika: sb. st. po materialam XIV mezhdunarodnoi nauchno-prakticheskoi konferentsii. [Wood-based panels: Theory and Practice: Proceedings of the XIV International scientific and practical conference]. St Petersburg, 2011, pp. 71-73. (in Russ.).

11. Antonov A.V., Alashkevich Iu.D., Petrusheva N.A., Chizhov A.P. Lesnoi i khimicheskii kompleksy - problemy $i$ resheniia: sb. st. po materialam vseros. nauch.-prakt. konf. [Forest and chemical complexes - Problems and Solutions: materials All-Russian scientific-practical conference]. Krasnoyarsk, 2011, vol. 1, pp. 202-204. (in Russ.).

12. Antonov A.V., Petrusheva N.A., Chizhov A.P., Iaroshenko K.O., Mukhamedshina L.M. Molodye uchenye v reshenii aktual'nykh problem nauki: sb. st. po materialam vseros. nauch.-prakt. konf. s mezhdunar. uchastiem. [Young scientists in solving urgent problems of science: Proceedings of All-Russian scientific-practical conference with international participation]. Krasnoyarsk, 2011, vol. 2, pp. 62-64. (in Russ.).

13. Antonov A.V., Alashkevich Iu.D., Petrusheva N.A., Chizhov A.P. Novye dostizheniia v khimii $i$ khimicheskoi tekhnologii rastitel'nogo syr'ia: sb. materialov V vseros. konf. s mezhdunar. uchastiem. [New advances in chemistry and chemical technology of vegetable raw materials: materials of V Russian conference with international participation]. Barnaul, 2012, pp. 429-432. (in Russ.).

Received January 21, 2016

Revised March 3, 2016

\footnotetext{
* Corresponding author.
} 